Article

\title{
A confirmatory Framework PLS-SEM for Construction Waste reduction as part of achieving Sustainable Development Goals of a building
}

\author{
Musa Mohammed 12*; Nasir Shafiq ${ }^{3^{*}}$; Ali Elmansoury4 5; Noor Amila Abdallah6; Abubakar Muhammad7, \\ ${ }^{1}$ Civil and Environmental Engineering Department Universiti Teknologi Petronas UTP, 32610 Seri Iskandar \\ Malaysia, musa_17006266@utp.edu.my. \\ ${ }^{2}$ Department of Building Technology Abubakar Tafawa Balewa University (ATBU), P.M.B 0248 Bauchi State, \\ Nigeria. \\ ${ }^{3}$ Department of Civil \& Environmental Engineering, University Technology PETRONAS, 32610 Seri Iskandar, \\ Perak, Malaysia, naasirshafiq@utp.edu.my. \\ ${ }^{4}$ Architectural Department, College of Engineering, Al-Azhar University, Egypt, mansory74@yahoo.com. \\ ${ }^{5}$ Faculty of Islamic Architecture, College of Engineering and Islamic Architecture, Umm Al-Qura University, \\ Makkah 21955, Saudi Arabia. \\ ${ }^{6}$ Department of Civil \& Environmental Engineering, University Technology PETRONAS, 32610 Seri Iskandar, \\ Perak, Malaysia, aamilawa@utp.edu.my. \\ 7 Department of Building Technology Abubakar Tafawa Balewa University (ATBU), P.M.B 0248 Bauchi State, \\ Nigeria, abumuhd01@yahoo.com. \\ * Correspondence author email: musa_17006266@utp.edu.my, naasirshafiq@utp.edu.my \\ (+60167630439) (+60165445930)
}

\begin{abstract}
As a result of rapid population growth, an exponentially growing human population, and industrial expansion, it has become increasingly difficult to manage municipal solid wastes throughout the world. Decentralized waste management systems have created difficult situations in developing countries such as Malaysia. Wastes generated in the country, due to various cultural, social, and religious activities, organic and contributing to environmental pollution (air, water, and soil) and human health troubles. A questionnaire survey was participated by 220 construction professionals in Malaysia using structured and semi-structured methods. The framework was assessed using A partial least square structural equation modeling (PLS-SEM) to target sustainable development goals (SDG). Statistical analysis results indicate a significant effect between SCW management, since $(\mathrm{r}(270)=.687, \mathrm{P}<0.001)$. Improving factors has strong relationship with SCW management, since $(\mathrm{r}(270)=.723, \mathrm{P}<0.001)$. The mediation results also suggested a significant indirect positive effect of improving factors drivers on SCW management through policy-related factors since $(\beta=0.688, t=8.254, \mathrm{P}<0.001,95 \% \mathrm{CI}$ for $\beta=[0.536,0.866])$. Finally, policy-related factors construct has a strong relationship with SCWM) management, since $(\mathrm{r}(270)=.811, \mathrm{P}<0.001)$ With the R Square of 0.787 and 0.785 . The developed framework can improve construction waste management in the construction industry and enhance construction waste management to achieve global sustainable development goals. The findings show that one of the most critical issues of enhancing profitability is using preventive policies to reduce construction waste. This study could guide construction industry stakeholders in identifying the different waste management features during a building project's construction and design stage
\end{abstract}

Keywords: Effective Construction; Waste Reduction; achieving Sustainable Development Goals; partial least square structural equation modeling (PLS-SEM).

\section{Introduction}

The construction industry generated 16.6 million tonnes of waste in 2007, comprising $38 \%$ of destruction (2019), and $43 \%$ of those wastes sent to landfills [1, 2]. The amount of 
waste generated is enormous in the processes of construction and demolition (C\&D). In $2020, C \& D$ waste was reported to account for about $26 \%$ of Malaysian solid waste [3]. The problems associated with $\mathrm{C} \& \mathrm{D}$ are increasingly becoming a nightmare to practitioners and researchers $[4,5]$. Furthermore, the amount of $C \& D$ waste continues to rise rapidly and is not entirely managed in most countries [6]. Therefore, the Architectural, Engineering, and Construction (AEC) industry should seek to minimize and manage C\&D waste more efficiently $[7,8]$. Many previous studies have suggested strategies for reducing C\&D waste by reusing and recycling it [9]. Construction waste reduction is the first step in minimizing C\&D waste. This is achieved by mitigating the root causes of waste $[10,11]$. Design defects left unattended during the construction process will need to fix through renovation works and or reconstruction after project completion. This renovation or reconstruction may demand changing or demolition of some of the structural elements, leading to the accumulation of waste [9]. Improper design and unexpected design changes have been considered the fundamental causes of waste generation in construction $[12,13]$. The inappropriate design has significantly led to an unexpected increase in construction waste total volume to about 33\%. [14]. With an integrated building design, the causes of construction waste can be minimized and prevented where necessary., design problems and improvements, thereby reducing the volume of waste generation $[15,16]$. In the work of Leemans, et al. [17], In Malaysia, residential and non-residential buildings use approximately $7.6 \%$ of total primary energy and emit about $6.0 \%$ of total (equivalent) carbon dioxide emissions as all direct and indirect contributions are listed for all major industries MILLHONE and Transfer [18]. The construction industry generated 16.6 million tonnes of waste in 2007 , comprising $38 \%$ of total waste (2019) and $43 \%$ of those sent to landfills. In most of the countries, solid wastes are being dumped into the landfill sites. However, there will be risks of economic loss as well as environmental pollution as a result of doing so[19]. Sludge (35 percent waste) is also generated by the pulp and paper industries, and it can be divided into three categories based on the level of contamination and the method of treatment [19].

These steps reduce the electricity use and CO2 emissions of a building's life cycle [20]. Initially, now there are significant costs incurred. Nevertheless, the expense of lowering the carbon emissions of a house is control by long-term gains in energy conservation, not to mention the ever-increasing energy prices [21]. As a consequence, the idea of low-carbon buildings and, eventually, the carbon-free building developed. Globalization and demographic changes, and rising income levels since the 1970s had influenced the Malaysian housing provision system. Since the 1970s, Malaysia has experienced rapid economic growth with rising per capita income and rapid urbanization. The important green policies such as the utilization of renewable energy (RE), the adoption of energy efficiency (EE), and the promotion of green technology (GT) for sustainable development and towards the construction industry. However, currently lack the profound management devices to assist in the robust evaluation and execution of CWM by constructing configuration stages [22].

However, Environmental systems have been contaminated due to a lack of proper waste management practices, which have had negative effects on living creatures (including humans) and have also contributed to the current economic crisis [23]. Hence, its management has become a global concern. Solid wastes can be divided into five major categories: municipal solid waste (MSW), construction and demolition debris, electrical waste, sludge, and food waste. MSW is the most common type of solid waste. This challenge of increasing MSW magnitude seems inevitable as it is a byproduct of human activities that is growing alarmingly faster than that of urbanization [24].

Furthermore, even though MSW contains a high proportion of recyclable materials, incineration or illegal dumping are common practices due to a lack of land for new landfill construction[24]. As a result, time must be given to developing appropriate waste management strategies, inviting all relevant stakeholders. Many developing countries have 
made significant strides in improving their solid waste management systems [24]. However, because of the varying nature of solid waste, it is difficult to manage solid waste in developing countries such as Malaysia, the world's second-most populous country[25]. Open dumping of waste or any organic waste and construction waste can cause many environmental problems, as its decomposition will promote the genesis of pathogens. On the other side, its proper management can produce many helpful resources such as biochar, fragrance, compost, natural colors, etc., and reduce the pressure on the environment. However, at the global level, Stakeholders for proper waste management (NGOs $1 / 4$ Non-Governmental Organizations, CIDB, WUCM, and Municipal Corporations. Murgia, et al. [26] explained construction waste is generated directly or indirectly through construction operations. A percentage of the plasterboard waste, for example, is hazardous and may have an impact on the affected areas. Although Malaysia has regulatory policies for managing the waste generation, such as Standard Specifications, it is still a developing country.

Local Government; Environmental Quality Act 1974 (EQA), governed by the Ministry of Environment and Climate Change. Malaysian Natural Resources and Environment Act 1994, as well as the Pembinaan Malaysia Act 1994 (PMA) These rules, however, do not completely cover all of the features of CIDB [33], which is why Construction waste management is a broad term. For example, the PPSPPA is more concerned with domestic issues. Rather than construction waste, instead of construction waste Furthermore, to keep track of the work of contractors and The CIDB plan, the Solid Waste Management, and Public Cleansing Corporation, and other activities in the future [33, 34], to develop a guideline for the management of construction waste. Zuofa and Ochieng [27] Sustainability and resilience Green Growth." Before that, the Malaysian development industry's primary controlling body, the (CIDB), pushed the Construction Industry Transformation Plan (CITP) for 2016-2020 to engage and strengthen the development industry. CITP developed to rely on four (4) main thrusts: efficiency, health and professionalism, and environmental sustainability. It is proposed that a study be conducted to close the knowledge gap by gathering or collecting empirical data from relevant professionals who are knowledgeable about the problems mentioned above. This paper investigates the factorial validity for effective construction waste management through an extensive literature review and questionnaire to achieve the sustainable development goal for more efficient construction waste management. The study's findings are expected to encourage practitioners, especially in small and medium construction firms, to utilize effective construction waste management for achieving sustainable development goals in the Malaysian construction industry.

Hence, effective construction waste management for achieving sustainable development goals in various regions of the world and Malaysia. This is being presented to the scientific Community to extract valuable products from waste to achieve this goal. To steer the construction industry in the right direction, all relevant parties should work together to ensure that waste is minimized by fully implementing waste material reduction, reuse, and recycling. This paper is organized as follows. The next section presents a literature review, explicitly focusing on effective construction waste management for achieving sustainable Development Goal benefits in construction waste minimization; the third section offers a brief description of the study's methodology. And the fourth section gives a detailed analysis and explanation of the data obtained. Finally, the last section presents the conclusion of the review and possible recommendations for future research.

\section{Overview and concept of waste reduction}

The key reason for waste management is to manage waste. Nonetheless, in particular, minimization of waste at the source is important for efficient waste management [28]. The Sixth Environment Action Plan identifies waste minimization as the main objective of the Community's waste program, and this concurrent focus of the recycling and disposal strategy results in a shortage of specific meanings of keywords [29]. According to Begum, 
et al. [30], waste minimization comprises several activities (including waste reduction, reuse, and recycling) that reduce waste entering the environment. In particular, waste minimization in the construction sector includes the processes, including but not restricted to: improvements, adjustments in inventory management, product design, material changes, changes in operation and maintenance methods, replacement or improvement of infrastructure, and re-use or recycling of waste materials [31]. While the exact language used to define the concept and its scope may vary among regulatory bodies, all definitions highlight the significance of avoiding the creation of waste rather than focusing on the management of residuals after they are generated.

Furthermore, waste minimization requires reducing or removing waste production at the source and environmentally sustainable recycling strategies when source mitigation is not economically sustainable. Waste minimization does not require waste treatment, i.e., any method designed to change the physical, chemical, or biological design or quality of hazardous waste or treatment of waste. For instance, pacification, dilution, compacting, and incineration are not waste minimization practices [32]. The strategy and process for reducing waste imply mitigating waste production at the environment and the specific stage. The broader aspect of the purpose related to waste management is generally known as a waste hierarchy. Thus, the continuation of constructing waste disposal facilities is not a good idea, and building and operating new disposal facilities is very costly. It could only lead to a higher refuse disposal fee [33].

\subsection{Root causes of construction waste}

The root causes of construction waste obtained from the primary sources are Architects' failure to enforce waste management strategies during Osmani and Sciences [34]. Mohammed, et al. [35] stated that construction waste generation by design. Numerous project stakeholders contribute directly or indirectly in a waste generation which includes last-minute client demands (resulting in rework); lack of expertise of planners in assessing building methods and the order of construction activities (leading to specification errors causing work to be modified or terminated); Lack of expertise of planners in assessing building methods and the order of construction activities (leading to specification errors causing work to be modified or terminated); Lack of expertise of planners in assessing building methods and the Uncertainty in the design (producing in off-cuts); Lack of design knowledge (resulting in over-ordering of materials due to decisions made by contractors and subcontractors); studies or laws, and regulations) Osmani, et al. [36] and Ghafourian, et al. [37]. Osmani, et al. [36] stated that waste produced during the design process is mainly due to: 'poor teamwork' which leads to errors and defects; and "Overlapping design and construction adds to the complexity of managing the design process and raises waste mitigation issues to the top of the priority list.. Osmani, et al. [36] identifies "the shortage of designers' expertise in evaluating construction techniques and the schedule of construction processes" as a significant cause of design variations during the construction phase.

Furthermore, the interpretation is the origin of waste production. It examines the causes and impacts of the numerous stated elements on the management of construction waste. The categories include design, labour management, procurement site condition handling, and external factor set. The list of the selected construction waste factors is shown in the Table. 1. 
Table 1: Causative Factors for Construction Waste Generation

\begin{tabular}{|c|c|c|}
\hline Group & Causes of Construction Waste & References \\
\hline Design & $\begin{array}{l}\text { Last-minute client requirements } \\
\text { Frequent design changes } \\
\text { Design errors } \\
\text { Frequent design changes } \\
\text { Errors in contract documentation } \\
\text { Lack of design information } \\
\text { Poor design quality } \\
\text { Poor coordination of parties during the design stage }\end{array}$ & $\begin{array}{l}\text { Migilinskas, et } \\
\text { al. [38], [39, 40] }\end{array}$ \\
\hline $\begin{array}{c}\text { Procure- } \\
\text { ment }\end{array}$ & $\begin{array}{l}\text { Waste resulting from packaging } \\
\text { Poor site condition } \\
\text { Interference of other crews at the site } \\
\text { Congestion of the site }\end{array}$ & {$[40,41]$} \\
\hline $\begin{array}{l}\text { Manage- } \\
\text { ment Fac- } \\
\text { tors }\end{array}$ & $\begin{array}{l}\text { Lack of coordination amongst parties } \\
\text { Lack of influence of contractors } \\
\text { Poor planning } \\
\text { Late information drift amongst parties } \\
\text { Rework } \\
\text { Lack of knowledge about construction } \\
\text { Poor quality information } \\
\text { Inappropriate methods of construction } \\
\text { Lack of environmental information } \\
\text { Communication problems }\end{array}$ & $\begin{array}{l}\text { Migilinskas, et } \\
\text { al. [38] }\end{array}$ \\
\hline $\begin{array}{l}\text { Construc- } \\
\text { tion Op- } \\
\text { eration/ }\end{array}$ & $\begin{array}{l}\text { Poor workmanship } \\
\text { Improper project planning } \\
\text { Poor supervision }\end{array}$ & {$[40,42,43]$} \\
\hline $\begin{array}{c}\text { Project } \\
\text { Manage- } \\
\text { ment }\end{array}$ & $\begin{array}{l}\text { Poor site conditions } \\
\text { Reworks Due to Errors } \\
\text { Leftover from cutting and shaping } \\
\text { Inadequate knowledge } \\
\text { Materials off-cuts }\end{array}$ & \\
\hline $\begin{array}{l}\text { Site Con- } \\
\text { dition }\end{array}$ & $\begin{array}{l}\text { Unforeseen ground conditions } \\
\text { Difficulties accessing the construction site } \\
\text { Leftover materials on site } \\
\text { Poor site condition } \\
\text { Waste resulting from packaging } \\
\text { Lighting problem }\end{array}$ & Wijesiri, 2011 \\
\hline $\begin{array}{l}\text { Han- } \\
\text { dling }\end{array}$ & $\begin{array}{l}\text { Poor Materials Storage } \\
\text { Poor Materials Handling }\end{array}$ & {$[44,45]$} \\
\hline
\end{tabular}

\subsection{Current Practice of Waste Management Construction in Malaysia}

Development in the standard of living led to rapid growth in the construction industries, and the demand for infrastructure projects, shifts in utilization patterns, and population growth contributed significantly to waste generation [46]. Construction waste consists of delays. $[47,48]$ mentioned that building waste might be hazardous, such as asbestos produced during the demolition of existing structures. It is, therefore, necessary to have a proper and well-defined policy and technology used in the management of waste produced from construction activities to reduce the adverse effect that may have on environmental, social, and economic aspects. 


\subsection{Construction Waste Management Policy}

With the advancement in sustainable improvements as a new norm, the construction industries have started to understand its harmful effects on the environment [47]. It is known that by nature, construction is not an environmentally friendly activity. The Negative Impact of the construction activities has been compressively reviewed by the researchers, including waste generation, resource depletion, land deterioration, and different forms of pollution [49-52]. In response, the Government of Malaysia has developed a Construction Industry Development Board (CIDB) agency to transform the industry by improving its environmental performance [53]. CIDB has produced a Master Plan for the Construction Industry to enhance sustainability awareness among the construction key players. In conjunction with this, the government of Malaysia has established Standard Building Works Specifications (SBW) governed by the Ministry of Works. At the same time, the 1994 Pembinaan Malaysia Act (PMA) is also governed by the CIDB). SBW's goal is to ensure twice a week garbage and construction clearance and send into landfill while PMA is to avoid and decrease pollution caused by building waste. All the policies and acts established by government bodies demonstrate the desire to manage building waste properly. Construction practitioners do not follow all policies implemented, however, and a more holistic policy is needed to ensure that economic, social, and environmental aspects can be protected.

\subsection{Waste Management Technologies}

Researcher Fercoq has indicated that the most environmentally sound measure for the waste management hierarchy should start with waste minimization, waste reuse, recycling, and ultimately composting. The adoption of waste minimization in the construction industry has shown its importance [47]. Minimization of waste involves reducing supply, which reduces waste generation at origin, and recycling, which reflects a recovery to recycling waste material [54]. Malaysia is moving towards adopting the Industrial Building System (IBS), which can control waste generation in construction activities and is environmentally friendly [55]. IBS is defined as a construction system that is built using a prefabricated component [56]. However, Mohammad and Sciences [57], due to higher initial costs, hinder construction professionals from adopting this method, although IBS may be one of the great ways to minimize on-site waste.

\subsection{Factors for improving waste management practices}

The interpretation on factors for improving waste management to mitigate the shortcomings of (CWM). C\&DW management hierarchy, including reducing, reuse, and recycling strategies, is discussed, after which the most essential contributing factors to C\&DW management are introduced. After determining the factors that impact C\&DW management, this study classifies those that help to further sustainable C\&DW management into four categories, which are the framework for sustainable C\&DW management, construction, management factors, and industry policy factors. Tables 2 and 3 illustrate some of the major contributing factors to the management of C\&D waste. The interpretation on drivers and factors for improving waste management to mitigate the shortcomings of (CWM) via application of 3r. The interpretation of drivers and factors for improving waste management to mitigate the shortcomings of (CWM) via 3 r. 
Table 2: Factors for Improving Waste Management

\begin{tabular}{|c|c|c|}
\hline Group & Factors for Improving Waste Management & References \\
\hline $\begin{array}{c}\text { Man- } \\
\text { power } \\
\text { Factors }\end{array}$ & $\begin{array}{l}\text { The commitment of the contractor's representa- } \\
\text { tive at the site } \\
\text { Appointment of laborers solely for waste disposal } \\
\text { Contribution \& cooperation of subcontractor } \\
\text { Waste management organizations broken-down } \\
\text { t structures. } \\
\text { Consistency in the language and manner used to } \\
\text { describe the details } \\
\text { Drawing documents are free of errors that could } \\
\text { otherwise lead to reworks } \\
\quad[59,60]\end{array}$ & {$[57,58]$} \\
\hline Group & $\begin{array}{l}\text { Factors for Improving Waste Management } \\
\text { (CWM) }\end{array}$ & References \\
\hline $\begin{array}{l}\text { Manage- } \\
\text { ment Fac- } \\
\text { tors }\end{array}$ & {$[59,60]$} & \\
\hline $\begin{array}{c}\text { Industry } \\
\text { Policy } \\
\text { Factor }\end{array}$ & $\begin{array}{l}\text { Obligatory cost estimation for the quantity of } \\
\text { waste treatment a bill } \\
\text { Adequate training to gain required competencies } \\
\text { and experience } \\
\text { Supervising waste management by a residential } \\
\text { officer } \\
\text { Additional tender premiums where waste initia- } \\
\text { tives to implemented } \\
\text { Feasibility studies of waste estimation techniques } \\
\text { Simplifying legal prosecutes to install waste treat- } \\
\text { ment equipment }\end{array}$ & {$[59,60]$} \\
\hline
\end{tabular}

\subsection{Construction waste Determinant for Sustainable Attributes}

Construction waste management techniques have been used for specific applications, methods, equipment, and final products through construction waste sources. For instance, techniques such as aggregate crushing, powder grinding, polishing, and ash burning would be used to control glass waste[47]. In tackling construction waste sustainably, The technique should be chosen from the possibilities based on its lengthy viability. Sustainable qualities contribute to long-term Development while also balancing environmental, social, and economic factors. Economic features address the financial benefit or expense of dealing with unique construction waste. Environmental qualities are used to assess the influence of waste management technology on the environment.

Nonetheless, Recently, social considerations have been imposed on building projects, requiring contractors to consider social aspects such as local jobs and neighborhood quality of life while selecting appropriate waste management strategies. It indicates that the criteria for assessing waste management activities differ from time to time. In this regard, it is important to establish an integrated system for choosing the preferred CWM method based on up-to-date, sustainable attributes.

Construction \& Demolition waste is a term that refers to the process construction Environmental Protection Agency (EPA) defines waste as "waste materials generated in the design, remodeling, or demolition of structures and roads." Materials resulting 
from natural calamities are also included [61]. Sustainable construction is also a critical strategy that can be regarded for sustained Development through deliberating on environmental, social, economic, and cultural issues. The need to uncover the balance between the economic, environmental, and social elements of the design, construction, and use of buildings is a more substantial meaning for sustainable construction. Indeed, sustainable construction is seen as a significant sub-component to drive sustainable development [62]. For example, Umar, et al. [63] highlight the benefits of high-performance C\&D waste management for a smooth building process while decreasing environmental impacts. It adheres to the two pillars of construction sustainability: resource conservation and pollution abatement [64]. As shown in Figure 1, sustainable construction mainly depends on waste management [65]; sustainable construction would have affected the evaluation of CWM performance. It is commonly agreed that the outcomes of the CWM are affected by environmental sustainability, social sustainability, and economic sustainability variables [6668].

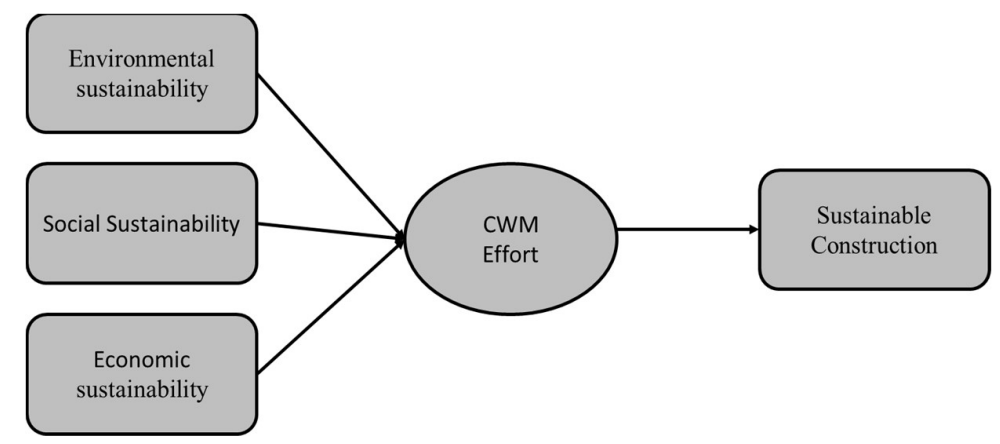

Figure 1. Novel and model for sustainable CWM

\section{Menials and Methods}

The proposed study applied two stages of analysis methods, namely variances-based structural equation modeling (PLS-SEM). A survey research strategy was used to collect data, including a questionnaire and walkthrough observational procedures. The Methodology questionnaire was adapted and used in the Malaysian construction industry. Before conducting the field survey, the questionnaire was pretested, and a pilot survey was conducted to ensure that it was accurate. Improving the questionnaire before the pilot survey, the pretest was conducted by discussing the questionnaire with colleagues[69].

A total of 220 questionnaires were administered to the respondents the local consultants and contractors registered with the Construction Industry Development Board (CIDB), out of which 131 representing 79 percent were retrieved of which 122 representing 74 percent of the total questionnaires distributed were considered valid for the analysis as recommended by Aziz, et al. [70] and [71] and a population of about 1000 for the field survey. According to the pilot study's findings, positive feedback was received in response to the questionnaire's design and presentation. It was refined in response to the pilot results to improve the questionnaire's face validity. The Statistical Package for Social Science (SPSS) version 21 was used in the preliminary analyses, was used for the Analysis. The data were screened to ensure univariate and multivariate normality as required [72]. The descriptive analysis of the categorical items was also carried out to determine the normality of the data. The mean, standard deviation, skewness, and kurtosis of the categorical items were used to determine the normality of the data. Later, factor analyses were conducted to determine the reliability and validity of using the factors in measurement models for evaluating public housing performance. These analyses included reliability, exploratory factor analyses, and confirmatory factor analyses. 


\section{Results}

Data collection was carried out by employing a questionnaire survey. It has been undertaken to demonstrate existing theories and reinforce research findings with previous research views and conclusions. Pretesting was carried out by discussing the questionnaire. It also entailed having the questionnaire evaluated by professionals in the same subject to ensure that the questions were relevant and that the questionnaire was simple and eligible. After collecting the data from the study area, the questionnaires were coded and posted into SPSS and subsequently transported to PLS-SEM. The analysis was carried out using frequency to identify missing data and wrong postings. Data were screened before using them for further analysis. That was important in ensuring that data used in analysis meet the criteria of normally distributed Parr, et al. [73] and was free from missing data. The questionnaires were of two different kinds. Variables used to develop the first questionnaire were obtained from the literature and other studies by Heberlein and Baumgartner [74]. Survey respondents include civil engineers, architects, quantity surveyors, and others (building designers and interior designers). The reliability and validity of using the variables in measurement models for effective CW management for assessment were then determined using reliability, exploratory, and confirmatory factor analyses. The following analysis discussed as follows.

\subsection{Profiles of respondents}

Following the data screening, the sample's demographic profiles with 122 instances were presented. The gender distribution indicated that about $85 \%$ of the respondents were males, and $15 \%$ were females. The data showed that more than $90 \%$ of the respondents were married and aged between 30 years to 60 years. Even though more than $73 \%$ of the respondents were civil servants, about $42 \%$ reported mostly at private companies. This probably indicated a significant number of the respondents are from construction companies in Malaysia.

\subsubsection{Data Reliability and validity of the Measurement Models}

A reliability test for all the constructs was carried out using Cronbach's alpha, as suggested by Taber [75]. Even though the recommended level is 0.7 Wong [76], The purpose of the reliability assessment is to test whether the consistency of the data in the questionnaire is consistent or not to obtain the correct results of the study. C and I received acceptable values of 0.882 and 0.815 , respectively, in the first repetition of field data. The value of the $P$ construct is 0.889 . Also, the variables under the $S$ had a value of 0.889 . A similar study by Eisinga, et al. [77] on BIM achieved the alpha value of 0.71 .

Table 4: Cronbach's Alpha

\begin{tabular}{ccc}
\hline Constructs & No. of items & Cronbach's alpha \\
\hline C & 122 & 0.882 \\
\hline $\mathrm{I}$ & 122 & 0.815 \\
\hline $\mathrm{P}$ & 122 & 0.889 \\
\hline
\end{tabular}

In this regard, the validity of the instrument used for this study is shown in the following Equation:

Validity $(\mathrm{v})=\sqrt{ } \alpha$

Equation 4.1

Where: $\alpha$ is the reality alpha value.

Therefore, Validity $(\mathrm{v})=\sqrt{0.882}=0.9391$

The results obtained indicate excellent validity. 


\subsubsection{Causes of construction waste generation in Malaysia.}

This section contains the Malaysian construction industry's causes and practices to manage and control sustainable construction waste management strategies in this study. Table 5: illustrates the results obtained from the respondents. The results are arranged from the highest mean to the lowest. The five most significant factors among all stakeholders were; Lack of Design and documentation (RD1) as the most critical factors that cause prevalent practices adopted by the Malaysian construction industry to manage and control the sustainable construction wastes management strategies and ranked first having a mean value of 2.90 and SD of 0.856 which is higher than all the remaining factors within the group. Transportation problem (RD2) ranked second, having a mean and S.D values of 2.88 and 0.845 , respectively. Incorrect Procurement (RD3) was ranked third with a mean and S.D values of 2.87 and 0.756 . Furthermore, the Lack of design standards for reducing C.D.W. (RD4) has a 2.83 mean with an S.D of 0.845 . Low cost for C.D.W. disposal (RD5) ranked fifth, having a mean and S.D values of 2.820 .761 , respectively.

Table 5: First mean ranking of causes of waste generation

\begin{tabular}{cclccc}
\hline Code & $\mathbf{N}$ & \multicolumn{1}{c}{ Constructs } & Mean. V & Std.Deviation & Rank \\
\hline RD1 & 266 & $\begin{array}{l}\text { Lack of Design and documenta- } \\
\text { tion }\end{array}$ & 2.90 & 0.856 & 1st \\
\hline RD2 & 266 & Transportation problem & 2.88 & 0.845 & 2nd \\
\hline RD3 & 266 & Incorrect Procurement & 2.87 & 0.756 & 3rd \\
\hline RD4 & 266 & $\begin{array}{l}\text { Lack of design standards for re- } \\
\text { ducing CDW }\end{array}$ & 2.83 & 0.832 & 4 th \\
\hline RD5 & 266 & Low cost for CDW disposal & 2.82 & 0.761 & 5 th \\
\hline
\end{tabular}

Table 6 shows the causes of construction waste generation and Malaysian practices adopted by many professionals in the Malaysian construction industry, which indicates that $(C D W)$. The reduction is significant. Most of them have no idea how to reduce C.D.W. in the design process. According to the results obtained and supported by Gouldson, et al. [78]. Lack of guidance for effective C.D.W. collection and sorting (RU1) has 2.92 mean with S. D of 0.845 and ranked first among the causes of low the Malaysian construction industry practices while Lack of knowledge and standards for reused (CDW). (RU2) having a mean value of 2.90 with an SD of 0.861 and ranked second among the causes of low practices. Also, an accident due to negligence (RU3) has a 2.89 mean value and SD 0.848 as part of the factors causing low the Malaysian construction industry practices and ranked third. Equipment malfunctioning (RU4) has a 2.73 mean value and an SD of 0.940. Lastly, in the group, Time pressure (RU5) has a 2.68 mean S.D of 0.979 and ranked fifth. 
Table 6: Second mean ranking of causes of waste generation

\begin{tabular}{cclccc}
\hline Code & N & \multicolumn{1}{c}{ Constructs } & Mean & Std.Deviation & Rank \\
\hline RU1 & 266 & $\begin{array}{l}\text { Lack of guidance for } \\
\text { effective C.D.W. collec- } \\
\text { tion and sorting }\end{array}$ & 2.92 & .845 & 1st \\
\hline RU2 & 266 & $\begin{array}{l}\text { Lack of knowledge and } \\
\text { standards for reused } \\
\text { CDW }\end{array}$ & 2.90 & .861 & 2nd \\
\hline RU3 & 266 & $\begin{array}{l}\text { Accident due to negli- } \\
\text { gence }\end{array}$ & 2.89 & .848 & 3rd \\
\hline RU4 & 266 & $\begin{array}{l}\text { Equipment malfunction- } \\
\text { ing }\end{array}$ & 2.73 & .940 & 4th \\
\hline RU5 & 266 & Time pressure & 2.68 & .979 & 5th \\
\hline
\end{tabular}

Moreover, Table 7. Illustrated the respondents' results indicating the under-developed market for recycled CDW. Products In Malaysia (RC1) is the most significant factor with a mean value of 2.94 with an SD of 0.845 . Immature recycling market operation (RC2) ranked second has 2.91 with an SD of 0.856 . Green recycling technology (RC3), with a mean value of 2.90 and SD of 0.848 , is the third-ranked factor among the causes of low practices adopted by the Malaysian construction industry.

Table 7: Third mean ranking of causes of waste generation

\begin{tabular}{llllll}
\hline Code & N & Constructs & Mean & Std. Deviation & Rank \\
\hline RC1 & 266 & The under-developed market for & 2.94 & 0.845 & 1st \\
& \multicolumn{2}{c}{$\begin{array}{l}\text { recycled CDW products In } \\
\text { Malaysia, }\end{array}$} & & 2nd \\
\hline RC2 & 266 & Immature recycling market & 2.91 & 0.856 & 3rd \\
\hline RC3 & 266 & Immature recycling technology & 2.90 & 0.848 & 4th \\
\hline RC4 & 266 & Damage during transportation & 2.89 & 0.845 & 5th \\
\hline RC5 & 266 & Difficulties for delivery vehicles & 2.31 & 0.832 & 6th \\
\hline RC6 & 266 & Inefficient method of unloading & 1.68 & 0.979 & \\
\hline
\end{tabular}

The summary of less significant factors was shown in Table8; the result showed that Damage during transportation (RC4) has 2.89 mean and SD of 0.848 and ranked fourth, while difficulties for delivery vehicles accessing construction sites (RC5) ranked fifth, has 2.31 mean. SD: 0.832 and Inefficient method of unloading (RC6) has a mean value of 1.68 and SD of 0.979 selected as less significant factors that cause standard practices adopted by the Malaysian construction industry to manage and control the sustainable construction wastes hence these factors chosen for further analysis.

\subsubsection{Barriers to Implementing Effective Construction Waste Management}

This section presents the barriers that impede effective construction and demolition waste management strategies in the Malaysian construction industry. The ranking of the 15 identified barriers is shown in Table 9. 
Table 9. The barrier to Implementing Effective Construction Waste Management Strategies

\begin{tabular}{llll}
\hline Barriers & Mean & S.D. & Rank \\
\hline Lack of attention to waste management in current regulations & 4.56 & 0.89 & 1 st \\
\hline Lack of attention to designing buildings according to requirements of waste & 4.36 & 0.96 & 2 nd \\
management & & & \\
\hline Lack of awareness among contractors about the waste management & 4.23 & 0.66 & 3 rd \\
\hline Lack of regulations to make waste management an obligation & 4.04 & 1.22 & 4 th \\
\hline Lack of incentives from regulatory authorities & 4.03 & 1.02 & 5 th \\
\hline Lack of culture in favor of waste management & 4.01 & 0.98 & 6 th \\
\hline Lack of support from owners and stakeholders & 3.91 & 0.95 & 7 th \\
\hline Lack of attention to waste management from the Community & 3.87 & 0.67 & 8 th \\
\hline Lack of economically viable facilities for waste management & 3.71 & 0.15 & 9 th \\
\hline Lack of waste management necessities within the national building codes & 3.65 & 0.88 & 10 th \\
\hline Low costs of sending materials to landfill & 3.47 & 0.88 & 11 th \\
\hline Lack of budget for managing waste & 3.45 & 0.56 & 12 th \\
\hline Low prices of building materials (waste management is not economically justified) & 3.41 & 0.74 & 13 th \\
\hline Lack of support from building supervisors & 3.21 & 0.79 & 14 th \\
\hline Tight scheduling of construction projects & 3.01 & 0.61 & 15 th \\
\hline
\end{tabular}

Table 9 shows the barriers to implementing effective construction and demolition waste management strategies in the Malaysian construction industry. As a result, using mean ranking, There is a lack of attention to waste management in current rules; there is a lack of attention to designing buildings according to waste management needs. There is a lack of attention to waste management in current regulations. Lack of waste management awareness among contractors; a lack of rules making waste management mandatory; and a lack of regulatory incentives, respectively having mean values of $4.56,4.36$, $4.23,4.04$, and 4.03 , are the 1 st to 5 th major barriers against the implementation of effective construction and demolition waste management strategies in the Malaysian construction industry.

Lack of waste management culture; Lack of support from owners and stakeholders; Lack of community attention to trash management; Lack of environmentally suitable waste management infrastructure; and The Lack of waste management requirements in national building codes was found to be the 6th to 10th biggest barrier to implementing efficient construction waste management strategies in Malaysia, with mean values of 4.01, $3.91,3.87,3.71$, and 3.65 .

The factors that were considered the least barriers to implementing effective construction and demolition waste management strategies in the Malaysian construction industry and ranked 11th to 15th were low costs of sending materials to landfill, Lack of budget for managing waste, low prices of building materials (waste management is not economically justified), Lack of support from building supervisors, and tight scheduling of construction projects as indicated by mean values of 3.47, 3.45, 3.41, 3.21 and 3.01 respectively.

\subsubsection{Descriptive statistics and multiple correlations}

Table 10 shows the results of descriptive statistics derived for the selected constructs. The mean (M), standard deviation (SD), and coefficient of variation (CV) are the three statistics in question. 
Table 10. Descriptive statistics for the selected constructs

\begin{tabular}{lccc}
\hline Construct & Mean & SD & CV \\
\hline Design Factors & 3.366 & 0.836 & $24.83 \%$ \\
\hline Design Development Stages / Lean Construction & 3.159 & 0.872 & $27.62 \%$ \\
\hline Construction \& Site Management & 3.007 & 0.919 & $30.54 \%$ \\
\hline External and Workers / Handling factors & 3.094 & 0.884 & $28.58 \%$ \\
\hline Planning And Design Factors & 2.905 & 0.937 & $32.26 \%$ \\
\hline Management Practices & 2.929 & 0.893 & $30.50 \%$ \\
\hline Construction Factors & 3.018 & 0.897 & $29.71 \%$ \\
\hline Waste Minimization Measures & 2.881 & 0.933 & $32.40 \%$ \\
\hline Effective to Improve CWM Factors & 2.841 & 0.873 & $30.73 \%$ \\
\hline Waste Management Policy Factors & 2.906 & 0.939 & $32.33 \%$ \\
\hline Industrial Factors & 2.820 & 0.869 & $30.81 \%$ \\
\hline Environmental Factors & 2.865 & 0.880 & $30.70 \%$ \\
\hline Economic Factors & 2.836 & 0.889 & $31.36 \%$ \\
\hline Social Factors & 4.029 & 0.853 & $21.17 \%$ \\
\hline Current Practices / Generation & 3.156 & 0.772 & $24.46 \%$ \\
\hline Improving Factors Drivers & 2.915 & 0.788 & $27.05 \%$ \\
\hline Policy Related Factors & 2.863 & 0.869 & $30.34 \%$ \\
\hline Sustainable Construction Waste Management & 3.244 & 0.671 & $20.70 \%$ \\
\hline
\end{tabular}

The descriptive statistics for the independent variables were as follows: for Current Practices / Generation, we have $(M=3.156, S D=0.772, C V=24.46 \%)$ and for Improving Factors Drivers, we have $(M=2.915, S D=0.788, C V=27.05 \%)$. The descriptive statistics for the mediator variable "Policy Related Factors" were as follows $(M=2.863, S D=$ $0.869, C V=30.34 \%)$. Finally, the descriptive statistics for the dependent variable "Sustainable Construction Waste Management" were as follows $(M=3.244, S D=0.671, C V=$ $20.70 \%)$.

Table 11. Pearson Multiple Correlations

\begin{tabular}{|c|c|c|c|c|}
\hline Construct & $\begin{array}{c}\text { Current } \\
\text { Practices / } \\
\text { Generation }\end{array}$ & $\begin{array}{c}\text { Improving } \\
\text { Factors } \\
\text { Drivers }\end{array}$ & $\begin{array}{c}\text { Policy } \\
\text { Related } \\
\text { Factors }\end{array}$ & $\begin{array}{c}\text { Sustainable } \\
\text { Construction } \\
\text { Waste Man- } \\
\text { agement }\end{array}$ \\
\hline Current Practices / Generation & 1 & $.815^{* * *}$ & $.685^{* * *}$ & $.687^{* * *}$ \\
\hline Improving Factors Drivers & & 1 & $.850^{* * *}$ & $.723^{* * *}$ \\
\hline Policy Related Factors & & & 1 & $.811^{* * *}$ \\
\hline Sustainable Construction Waste Management & & & & 1 \\
\hline
\end{tabular}

Table 11 shows the matrix of Pearson correlation coefficients between all variables in the study. The correlation coefficients suggest a significant positive (moderate to strong) correlation among all variables. Pearson product-moment correlation coefficient was calculated and found that there is a moderate positive relationship between Current Practices/Generation and Sustainable Construction Waste Management, since $(r(270)=$ $.687, P<0.001)$. Improving Factors Drivers construct has a strong relationship with Sustainable Construction Waste Management, since $(r(270)=.723, P<0.001)$. Finally, the 
Policy Related Factors construct has a strong relationship with Sustainable Construction Waste Management, since $(r(270)=.811, P<0.001)$.

\subsubsection{Structural Equation Modeling}

In this study, the researcher has applied structural equation modeling (SEM) for the model analysis. The SEM is a broad strategy to test hypotheses and determine the relationship between exogenous and endogenous variables. A partial least square analysis of SEM (PLS-SEM) is followed in this study. The first stage of this technique is about specifying the structural model, while the second stage is about defining the measurement models. The third stage focuses on collecting and examining the data. These three stages have been implemented in (Ch.). The fourth stage involves PLS-SEM path model estimation, while the fifth stage requires assessing the measurement model's results. The sixth stage is for assessing the results of the structural model. The final stage is making final interpretations of the results and conclusions. 


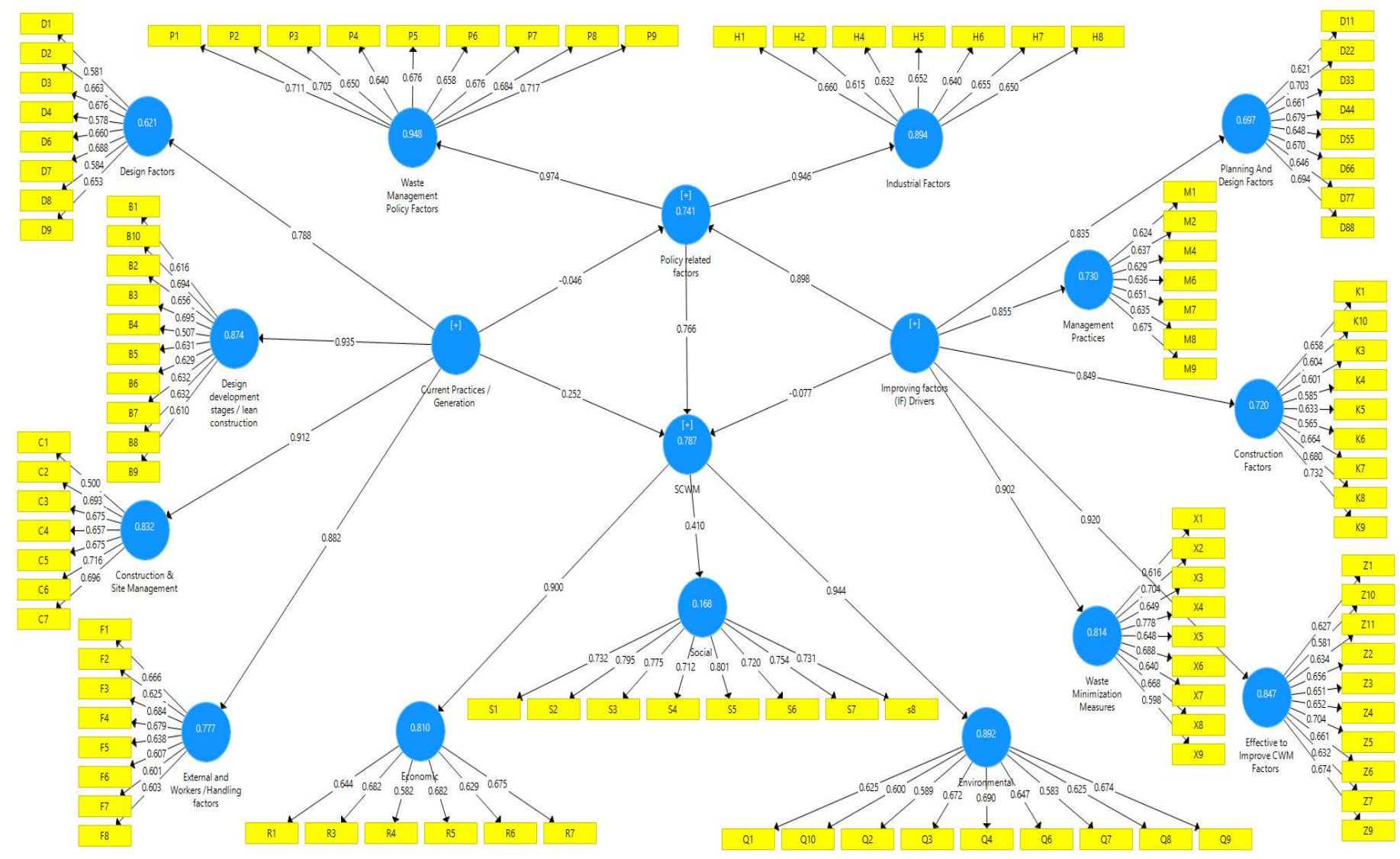

Figure 2, Output loading factor research mode 


\subsubsection{Assessing the Measurement Model}

The assessment of the reflective measurement models in PLS-SEM requires evaluating the internal consistency reliability, convergent validity, and discriminant validity. Fig (4.1) shows the measurement model of the current study. Once the reliability and validity of the measurement model have been established, the structural model will be assessed. The following subsections will discuss the reliability and validity of the measurement model.

\subsubsection{Internal reliability and convergent validity}

The internal consistency reliability examines whether all of the indicators associated with a constructed measure it [79]. There are different ways to measure internal consistency. Cronbach's alpha is a statistical measure that is the most commonly used for this purpose.

Table 12: Internal reliability and convergent validity

\begin{tabular}{llllll}
\hline Construct & $\begin{array}{l}\text { Cronbach's } \\
\text { Alpha }\end{array}$ & rho_A & CR & $\begin{array}{l}\text { AVE } \\
\text { Initial }\end{array}$ & Modified \\
\hline Design Factors & 0.79 & 0.793 & 0.845 & 0.366 & 0.406 \\
Design Development Stages / Lean Construction & 0.831 & 0.834 & 0.869 & 0.4 & 0.4 \\
Construction \& Site Management & 0.783 & 0.79 & 0.844 & 0.438 & 0.438 \\
External and Workers / Handling factors & 0.792 & 0.794 & 0.846 & 0.408 & 0.408 \\
Planning And Design Factors & 0.82 & 0.821 & 0.864 & 0.443 & 0.443 \\
Management Practices & 0.762 & 0.763 & 0.83 & 0.369 & 0.411 \\
Construction Factors & 0.816 & 0.82 & 0.86 & 0.392 & 0.407 \\
Waste Minimization Measures & 0.843 & 0.847 & 0.878 & 0.445 & 0.445 \\
Effective to Improve CWM Factors & 0.846 & 0.848 & 0.878 & 0.386 & 0.42 \\
Waste Management Policy Factors & 0.854 & 0.855 & 0.886 & 0.463 & 0.463 \\
Industrial Factors & 0.764 & 0.764 & 0.832 & 0.378 & 0.414 \\
Environmental Factors & 0.814 & 0.816 & 0.858 & 0.388 & 0.403 \\
Economic Factors & 0.725 & 0.727 & 0.814 & 0.334 & 0.422 \\
Social Factors & 0.891 & 0.894 & 0.913 & 0.567 & 0.567 \\
\hline
\end{tabular}

Cronbach's alpha provides the average correlation between all of the indicators that belong to one construct. The accepted value of Cronbach's alpha is 0.7; all weights of Cronbach's alpha in Table (4.18) were above 0.7. Despite its popularity, Cronbach's alpha is criticized for assuming that all of the indicators have equal outer loadings [80] and that the number of indicators influences the calculation of Cronbach's alpha in that fewer items produces lower value, especially in scales with items fewer than 10 [80].

Due to the limitations of Cronbach's alpha, researchers are advised to use other measures of internal consistency such as composite reliability (CR) and rho [81]. Jöreskog rho measure is a better reliability measure than Cronbach's alpha in structural equation modeling. It is based on the loadings rather than the correlations observed between the observed variables [81]. Composite reliability measures the internal consistency while considering that each indicator has a different outer loading. Following the previous rules, the reliability of each construct was assessed using the calculations provided in Smart PLS. The results in Table (4.18) show that all constructs had reliability (Cronbach's Alpha, rho, and Composite Reliability) scores of more than 0.70. Figures (4.18) present the results of the internal consistency reliability. Those findings provide evidence of the high reliability and sufficient internal consistency of the constructs. The convergent validity 
evaluates the correlation between the variables that measure one construct. The convergent validity of reflective measurement models is usually evaluated using the outer loadings of the items and the average variance extracted (AVE).

\subsubsection{Discriminant Validity}

Discriminant validity examines how much a construct differs from other constructs. Discriminant validity is usually established using the Fornell-Larcker criterion, crossloadings, or Hetrotrait-Monotrait (HTMT) ratio. The Fornel Larcker criterion, the square root of AVE, is compared against the construct's correlations. The square root of the construct's AVE should be higher than any of the construct's correlations with other constructs; the results of the Fornell-Larcker criterion were reported in Table (13). HTML is "the ratio of the between-trait correlations to the within-traits correlations. The HTMT value in Table (13) should be lower than 0.9 [361]. Following these guides, the results reveal that the discriminant validity is agreed. The third method, the cross-loading criterion, has also been used in this study to determine discriminatory validity. This method attempts to determine that the loading of indicators on a given latent construct should be higher than the loading on all other constructs by row. In other words, the loading of the indicators (items) of their constructs should be higher than the loading of another construct. Table 4.20 showed that the loading of all indicators of the allocated latent construct is higher than the cross-loading on other constructs (by row). The result showed a substantial degree of unidimensionality for each construct. 
Table 13. Item Loading

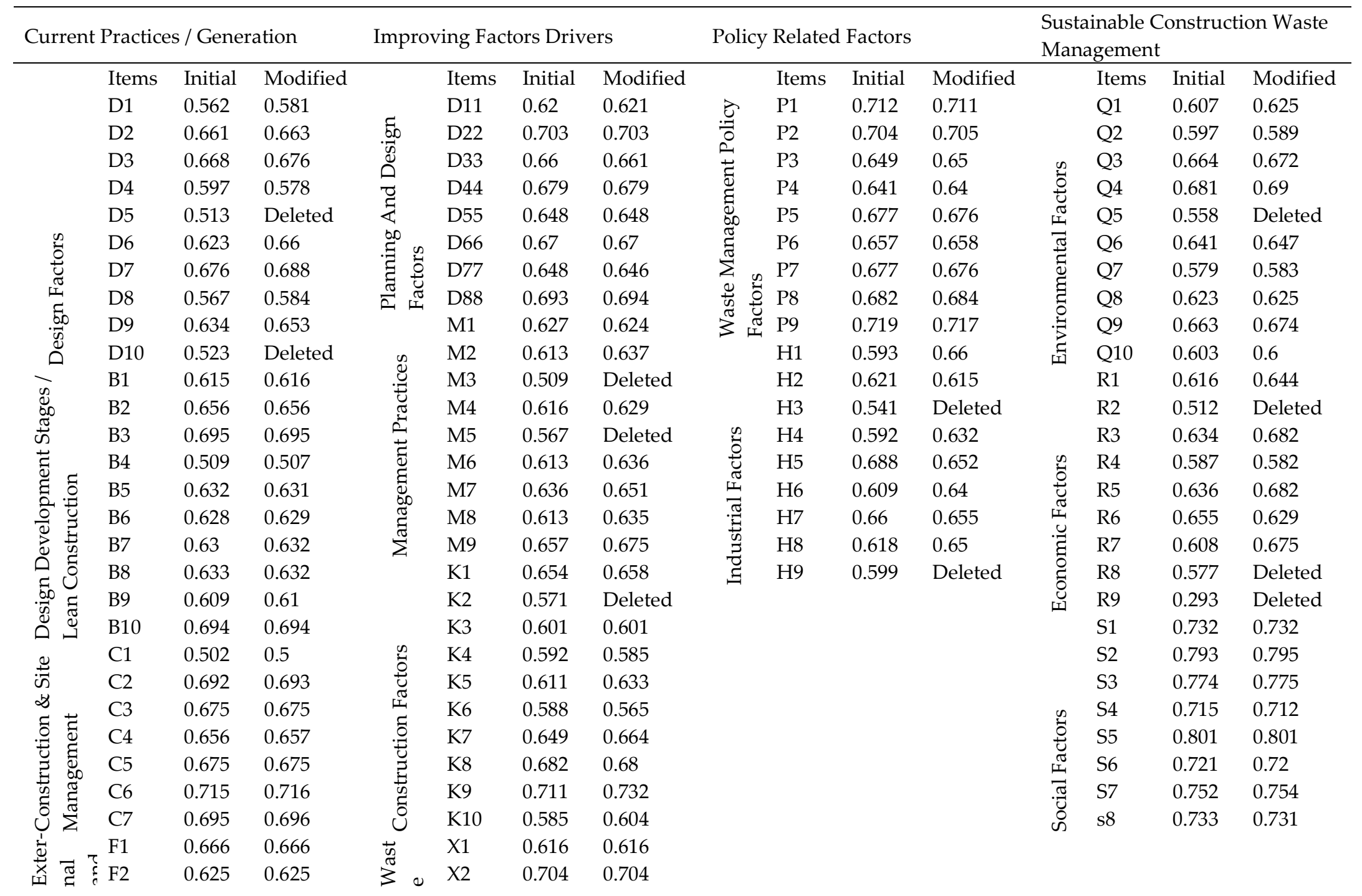


Table 14: Fornell-Larcker criterion

\begin{tabular}{|c|c|c|c|c|c|c|c|c|c|c|c|c|c|c|}
\hline & $\mathrm{m} 1$ & $\mathrm{~m} 2$ & $\mathrm{x} 11$ & $\mathrm{x} 12$ & $\mathrm{x} 13$ & $\mathrm{x} 14$ & $\mathrm{x} 21$ & $\mathrm{x} 22$ & $\mathrm{x} 23$ & $\mathrm{x} 24$ & $\mathrm{x} 25$ & $\mathrm{y} 1$ & $\mathrm{y} 2$ & $\mathrm{y} 3$ \\
\hline $\mathrm{m} 1$ & 0.68 & & & & & & & & & & & & & \\
\hline $\mathrm{m} 2$ & 0.50 & 0.644 & & & & & & & & & & & & \\
\hline $\mathrm{x} 11$ & 0.525 & 0.477 & 0.637 & & & & & & & & & & & \\
\hline $\mathrm{x} 12$ & 0.592 & 0.565 & 0.602 & 0.632 & & & & & & & & & & \\
\hline
\end{tabular}




\begin{tabular}{lllllllllllllllllll} 
x13 & 0.611 & 0.59 & 0.599 & 0.601 & 0.662 & & & & & & & & & \\
x14 & 0.616 & 0.639 & 0.574 & 0.552 & 0.553 & 0.639 & & & & & & & & \\
x21 & 0.615 & 0.638 & 0.489 & 0.582 & 0.561 & 0.594 & 0.666 & & & & & & & \\
x22 & 0.630 & 0.551 & 0.485 & 0.597 & 0.607 & 0.557 & 0.643 & 0.641 & & & & & & \\
x23 & 0.601 & 0.521 & 0.523 & 0.585 & 0.601 & 0.621 & 0.605 & 0.611 & 0.638 & & & & & \\
x24 & 0.562 & 0.563 & 0.492 & 0.563 & 0.602 & 0.588 & 0.642 & 0.631 & 0.60 & 0.667 & & & & \\
x25 & 0.593 & 0.509 & 0.518 & 0.579 & 0.592 & 0.615 & 0.61 & 0.601 & 0.610 & 0.650 & 0.648 & & & \\
y1 & 0.594 & 0.551 & 0.549 & 0.613 & 0.630 & 0.578 & 0.598 & 0.606 & 0.510 & 0.640 & 0.59 & 0.635 & & \\
y2 & 0.305 & 0.587 & 0.477 & 0.546 & 0.582 & 0.599 & 0.563 & 0.539 & 0.608 & 0.601 & 0.525 & 0.517 & 0.65 & \\
y3 & 0.147 & 0.128 & 0.255 & 0.237 & 0.158 & 0.202 & 0.127 & 0.1 & 0.137 & 0.109 & 0.139 & 0.185 & 0.147 & 0.753 \\
\hline
\end{tabular}


Table 15: HTMT ratio

\begin{tabular}{|c|c|c|c|c|c|c|c|c|c|c|c|c|c|}
\hline & $\mathrm{m} 1$ & $\mathrm{~m} 2$ & $\mathrm{x} 11$ & $\mathrm{x} 12$ & $\mathrm{x} 13$ & $\mathrm{x} 14$ & $\mathrm{x} 21$ & $\mathrm{x} 22$ & $\mathrm{x} 23$ & $\mathrm{x} 24$ & $\mathrm{x} 25$ & y1 & $\mathrm{y} 2$ \\
\hline $\mathrm{m} 2$ & 0.70 & & & & & & & & & & & & \\
\hline $\mathrm{x} 11$ & 0.635 & 0.612 & & & & & & & & & & & \\
\hline $\mathrm{x} 12$ & 0.705 & 0.712 & 0.812 & & & & & & & & & & \\
\hline x13 & 0.747 & 0.766 & 0.759 & 0.687 & & & & & & & & & \\
\hline x14 & 0.747 & 0.825 & 0.719 & 0.727 & 0.78 & & & & & & & & \\
\hline $\mathrm{x} 21$ & 0.731 & 0.808 & 0.602 & 0.828 & 0.852 & 0.786 & & & & & & & \\
\hline $\mathrm{x} 22$ & 0.772 & 0.848 & 0.622 & 0.75 & 0.788 & 0.843 & 0.737 & & & & & & \\
\hline $\mathrm{x} 23$ & 0.852 & 0.61 & 0.655 & 0.707 & 0.751 & 0.772 & 0.733 & 0.895 & & & & & \\
\hline $\mathrm{x} 24$ & 0.611 & 0.653 & 0.594 & 0.79 & 0.862 & 0.842 & 0.768 & 0.851 & 0.833 & & & & \\
\hline $\mathrm{x} 25$ & 0.671 & 0.701 & 0.632 & 0.811 & 0.834 & 0.873 & 0.848 & 0.843 & 0.839 & 0.799 & & & \\
\hline y1 & 0.689 & 0.812 & 0.684 & 0.748 & 0.82 & 0.844 & 0.733 & 0.766 & 0.86 & 0.737 & 0.752 & & \\
\hline y2 & 0.696 & 0.804 & 0.625 & 0.705 & 0.769 & 0.794 & 0.731 & 0.725 & 0.788 & 0.889 & 0.729 & 0.780 & \\
\hline y3 & 0.173 & 0.162 & 0.302 & 0.275 & 0.196 & 0.233 & 0.154 & 0.153 & 0.169 & 0.147 & 0.172 & 0.22 & 0.181 \\
\hline
\end{tabular}

\subsubsection{Assessing the Structural Model}

After establishing the reliability and validity of the measurement models, it is time to assess the structural model. Researchers in the literature provided guidelines for evaluating and reporting the structural model, including collinearity, path coefficients, coefficient of determination (R2), effect size $\left(\mathrm{f}^{2}\right)$, predictive relevance $(\mathrm{Q} 2)$, and goodness of fit (GoF) index.

\subsubsection{Collinearity}

Collinearity occurs when there is a high correlation between two constructs, producing interpretation issues[82]. Collinearity can be assessed using the variance inflation factor (VIF); a VIF value of 5 or higher indicates high collinearity [83]. Table (4.10) shows that most VIF values were below the cut-off point, providing evidence that the collinearity problem between independent constructs does not exist.

Table 16. Variance inflation factors

\begin{tabular}{lcc}
\hline Construct & Policy Related Factors & $\begin{array}{c}\text { Sustainable Construction Waste } \\
\text { Management }\end{array}$ \\
\hline Policy Related Factors & & 3.865 \\
Current Practices / Generation & 2.954 & 2.962 \\
Improving Factors Drivers & 2.954 & 3.072 \\
\hline
\end{tabular}

\subsection{Path Coefficients}

Path coefficients refer to the estimates of the relationships between the model's constructs[84]. Those coefficients range from +1 to -1 , where +1 means a strong positive relationship, 0 means a weak or non-existence relationship, and -1 means a strong negative relationship. Figure (4.4) shows the estimated model with the estimated path coefficients of the leading hypotheses along with the corresponding p-values. 
Table 17: Hypothesis testing

\begin{tabular}{|c|c|c|c|c|c|}
\hline \multirow{2}{*}{ Path } & \multirow{2}{*}{$\boldsymbol{\beta}$} & \multirow{2}{*}{ T-value } & \multirow{2}{*}{ P-value } & \multicolumn{2}{|c|}{$95 \% \mathrm{CI}$} \\
\hline & & & & $\mathrm{LL}$ & UL \\
\hline \multicolumn{6}{|l|}{ Direct Effect } \\
\hline $\begin{array}{l}\text { H1: Current Practices / Generation -> Policy Related } \\
\text { Factors }\end{array}$ & -0.046 & 0.619 & $0.537 \mathrm{NS}$ & -0.217 & 0.071 \\
\hline $\begin{array}{l}\text { H2: Current Practices / Generation -> Sustainable } \\
\text { Construction Waste Management }\end{array}$ & 0.252 & 4.878 & $0.000 * * *$ & 0.166 & 0.342 \\
\hline $\begin{array}{l}\text { H3: Improving Factors Drivers }->\text { Policy Related } \\
\text { Factors }\end{array}$ & 0.898 & 14.39 & $0.000 * * *$ & 0.798 & 1.025 \\
\hline $\begin{array}{l}\text { H4: Improving Factors Drivers } \quad->\text { Sustainable } \\
\text { Construction Waste Management }\end{array}$ & -0.077 & 1.043 & $0.3 \mathrm{NS}$ & -0.211 & 0.066 \\
\hline $\begin{array}{l}\text { H5: Policy Related Factors -> Sustainable Construction } \\
\text { Waste Management }\end{array}$ & 0.766 & 12.133 & $0.000 * * *$ & 0.626 & 0.871 \\
\hline \multicolumn{6}{|l|}{ Indirect Effect } \\
\hline $\begin{array}{l}\text { H6: Current Practices / Generation -> Policy Related } \\
\text { Factors -> Sustainable Construction Waste Management }\end{array}$ & -0.035 & 0.584 & $0.561 \mathrm{NS}$ & -0.188 & 0.05 \\
\hline $\begin{array}{l}\text { H7: Improving Factors Drivers }->\text { Policy Related } \\
\text { Factors -> Sustainable Construction Waste Management }\end{array}$ & 0.688 & 8.254 & $0.000 * * *$ & 0.536 & 0.866 \\
\hline
\end{tabular}

$$
{ }^{*} \mathrm{P}<0.05 ;{ }^{* *} \mathrm{P}<0.01 ;{ }^{* * *} \mathrm{P}<0.001 ;{ }^{\mathrm{NS}} \text { Not significant }
$$

The results of the hypotheses show that; Current Practices / Generation has no statistical significant effect on Policy Related Factors since $(\beta=-0.046, t=0.619, P>$ $0.05,95 \%$ CI for $\beta=[-0.217,0.071]$ )So H1 is rejected. However, Current Practices / Generation has a statistically significant positive effect on Sustainable Construction Waste Management since $(\beta=0.252, t=4.878, P<0.001,95 \% C I$ for $\beta=[0.166,0.342])$ So H2 is accepted. Improving Factors Drivers construct a statistically significant positive effect on Policy Related Factors since $(\beta=0.898, t=14.39, P<0.001,95 \% C I$ for $\beta=$ $[0.798,1.025])$ So H3 is accepted. Improving Factors Drivers construct no statistically significant effect on Sustainable Construction Waste Management since $(\beta=-0.077, t=$ $1.043, P>0.05,95 \% C I$ for $\beta=[-0.211,0.066])$ So H4 is rejected. Policy Related Factors has a statistically significant positive effect on Sustainable Construction Waste Management since $(\beta=0.766, t=12.133, P<0.001,95 \% C I$ for $\beta=[0.626,0.871])$ So H5 is accepted. The mediation analysis revealed that there is no indirect effect of Current Practices / Generation on Sustainable Construction Waste Management through Policy Related Factors since $(\beta=-0.035, t=0.584, P>0.05,95 \% C I$ for $\beta=[-0.188,0.05])$. The mediation results also suggested a significant indirect positive effect of Improving Factors Drivers on Sustainable Construction Waste Management through Policy Related Factors since $(\beta=0.688, t=8.254, P<0.001,95 \% C I$ for $\beta=[0.536,0.866])$. 


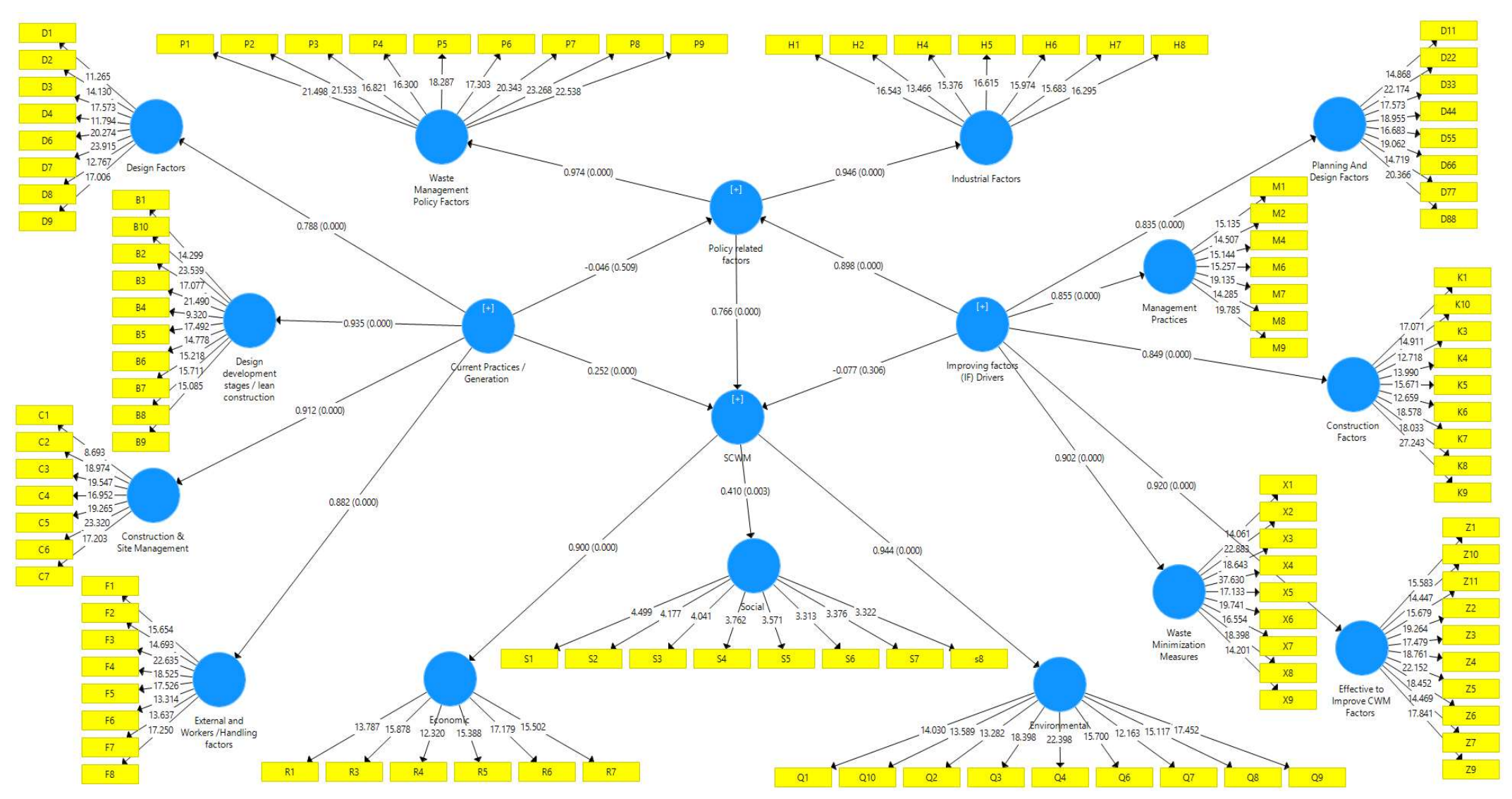

Fig 3: A structural equation modeling the main hypothesis 


\subsubsection{Coefficient of Determination}

Coefficient of determination $\left(R^{2}\right)$ refers to the effect of independent variables on the latent dependent variables, one of the structural model [84]. Hair Jr, et al. [85] suggested that $R^{2}$ with $0.19,0.33$, or 0.67 are low, moderate, or high, respectively. Furthermore, the adjusted $R^{2}$ values are useful in assessing the quality of various models or comparing the model across different contexts. The results were reported in Table (18), and the variations in the exogenous variables show high variations in the endogens variables[86].

Table 18: R Square and Associated R Square Adjusted

\begin{tabular}{lccc}
\hline Construct & R Square & $\begin{array}{c}\text { R Square } \\
\text { Adjusted }\end{array}$ & $\begin{array}{c}\text { Variance } \\
\text { Explained }\end{array}$ \\
\hline Policy Related Factors & 0.741 & 0.739 & High \\
\hline Sustainable Construction Waste Management & 0.787 & 0.785 & High \\
\hline
\end{tabular}

\subsubsection{Effect Size $\left(f^{2}\right)$}

The $f^{2}$ effect size measures how many impacts the endogenous construct will have if an exogenous construct was removed from the model. A construct is considered to have a small effect if its $f^{2}$ value is between 0.02 and 0.14 , while it is considered to have a medium effect if its $f^{2}$ value is between 0.15 and 0.34 , and a large effect if its $f^{2}$ value $\geq$ 0.35 . A construct with an $f^{2}$ value $<0.02$ means it does not affect the endogenous construct [87]. Table (4.13) presents the $f^{2}$ the effect size of the constructs. The results illustrate that Current Practices / Generation does not affect Policy Related Factors and large effect on Sustainable construction waste management. Improving Factors drivers have a large impact on policy-related factors and no effect on Sustainable Construction Waste Management. Finally, Policy Related Factors have a large effect on Sustainable Construction Waste Management.

Table 19: Predictive Relevance

\begin{tabular}{cccc}
\hline Construct & SSO & SSE & $\mathbf{Q}^{\mathbf{2}}$ (=1-SSE/SSO) \\
\hline Policy Related Factors & 4320 & 3031.281 & 0.298 \\
Sustainable Construction Waste Management & 6210 & 4985.28 & 0.197 \\
\hline
\end{tabular}

\subsubsection{Goodness of Fit of the Model}

Henseler and Sarstedt [88] Proposed the Goodness of Fit (GoF) as a global fit indicator; it is the geometric mean of both the average $R^{2}$ the average variance extracted of the endogenous variables. Where R2 is the structural model. Simultaneously, the AVE (communality) addresses the quality of the measurement models in the index. GoF index is considered small, medium, and large if the values are $0.1,0.25$, and 0.36 , respectively[89].The GoF index can be calculated as follow:

$G O F=\sqrt{\overline{R^{2}} \times \overline{A V E}}=\sqrt{0.764 \times 0.4319}=0.574$.

The criteria of GoF for deciding whether GoF values are; not acceptable (less than 0.1), small (between 0.1 to 0.25 ), moderate (between 0.25 to 0.36 ), or high (above 0.36 ) to be regarded as a globally appropriate PLS model. Therefore, according to these criteria, and the value of the Gof is (0.574), it can be safely concluded that the GoF model is large enough to be considered a sufficient valid global PLS-SEM model. Based on the[90], the model GoF of 0.39 is considered large. Therefore, the research model is fitted very well. The structural model is, therefore, good. 


\section{Discussion}

\subsection{Barriers to implementing effective C\&D waste management strategies}

The most significant obstacles to implementing effective building waste management solutions in Malaysia's city were discovered to be: There is a lack of attention to waste management in current regulations; there is a lack of attention to designing buildings according to waste management requirements; there is a lack of waste management awareness among contractors; there are no rules that make waste management mandatory, and there are no incentives from regulatory authorities. This finding confirmed that of [91], They discovered that the problems above prevent developing countries from implementing effective building and demolition waste management. Malaysia is no different., as [92] observed that C\&D waste management legislations are deficient in Malaysia. Lack of culture in favor of waste management; Lack of support from owners and stakeholders; Lack of attention to waste management from the Community; Lack of economically viable facilities for waste management; and Lack of waste management necessities within the national building codes were found to be the 6 th to 10th among the barriers hampering implementation of effective C\&D waste management strategies in Malaysia. This finding is in agreement with [13]. The variables are deemed the least obstructive to the Malaysian construction industry's implementation of effective construction and demolition waste management techniques. Low costs of shipping materials to landfills rated them 11 th to 15 th.

The finding agrees with [93], [94] and [95]. The main barriers to the proper implementation of waste reduction strategy occur when actors in the construction industry are vulnerable to communicating and cooperating. Stakeholders properly do not have a common understanding among themselves regarding 3R CW management strategies due to the similarity of reducing reuse and recycling strategies. Construction actors will take advantage of all aspects of reduction strategy if reduction strategy is included in the C\&DW management cycle for waste minimization; therefore, it is vital to pay extra attention to the reduction strategy's execution. Regarding the rapid growth of the CW generation worldwide, it is crucial to consider high priority in reducing strategy in the construction industry [96].

\subsection{Impact of improving factors on SCW management}

The respondents were asked to measure the effect of BIM design on sustainable construction waste during the building's design and construction using a scale of 1-5 (Very high to very low). The results revealed that Improving factors have a strong relationship with SCW management, since $(\mathrm{r}(270)=.723, \mathrm{P}<0.001)$ and R Square of 0.787. Assessment and brief design step specific (CWM). Improvements related to briefing requirements were identified during the evaluation and Brief design stages as presented in the work of Liu, et al. [97]. ment

\subsection{Impact on policy-related factors on Sustainable construction waste manage-}

The results indicate that policy-related factors have a significant moderating effect with sustainable construction waste management by constituting The mediation results also suggested a significant indirect positive effect of improving factors drivers on SCW management through policy-related factors since $(\beta=0.688, \mathrm{t}=8.254, \mathrm{P}<0.001,95 \% \mathrm{CI}$ for $\beta=$ $[0.536,0.866])$. Finally, policy-related factors construct has a strong relationship with SCWM) management, since $(\mathrm{r}(270)=.811, \mathrm{P}<0.001)$ and the R Square of 0.785. It is well-aligned with the work of Bamgbade, et al. [98], Samari (2012), government funding is the most successful in stimulating green construction, as it is more result-oriented than other techniques that can drive to progress sustainable construction waste management. Also, governments can enhance the adoption of sustainable construction waste management in several ways. The research of Bamgbade, et al. [98] stated that government could drive sustainable construction waste agendas with several policies, including fiscal supports, legislation and standards, and building labeling with energy efficiency rating in the Malaysian construction industry. This process may transform into the waste management system, which comprises reduction, minimization, reuse, recycling, recovery, and construction waste disposal. Many researchers have sported the above result $[47,99-102]$ - various sustainable waste management steps on government policy-related factors.

\subsection{Conclusion}

This paper presented the research on prevention approaches using BIM-based design for construction waste management in Malaysian projects. The following conclusions were 
drawn at the accomplishment of research objectives: The factors that course construction waste generation was identified through extensive literature review and descriptive statistic, Impact of Improving factors on SCW management contain correlation analysis and Impact on policy-related factors on Sustainable construction waste management constitute with PLSSEM formwork. A questionnaire was developed to obtain the required information for the study from the relevant professionals. Cronbach alpha was calculated to determine the reliability and validity of the instrument. The calculated reliability and validity of the instrument are $0.882,0.815$, and 0.889 , respectively. SEM was determined to be the most appropriate statistical analysis technique for this study. Based on their findings, the authors stressed that employees must use data when solving quality-related problems. Customer satisfaction $(\mathrm{r}=$ $0.29)$ and operational performance $(r=0.30)$ are both statistically significant at the $\mathrm{p}$-value of 0.05. Statistical analysis results indicate a significant effect between Sustainable Construction Waste management, since $(\mathrm{r}(270)=.687, \mathrm{P}<0.001)$. Improving factors has a strong relationship with Sustainable Construction Waste management, since $(\mathrm{r}(270)=.723$, $\mathrm{P}<$ 0.001). The mediation results also suggested a significant indirect positive effect of improving factors drivers on Sustainable Construction Waste management through policy-related factors since $(\beta=0.688, t=8.254, \mathrm{P}<0.001,95 \% \mathrm{CI}$ for $\beta=[0.536,0.866]) . \quad \mathrm{Fi}-$ nally, policy-related factors construct has a strong relationship with SCWM) management, since $(\mathrm{r}(270)=.811, \mathrm{P}<0.001) \quad$ With the $\mathrm{R}$ Square of 0.787 and 0.785 . The results may also be helpful to many construction companies, particularly those in developing countries where there is a lot of construction waste with low awareness. It can assist small and medium construction companies to become extremely sustainable and technologies for practical and sustainable manner. The barriers against the implementation of effective construction and demolition waste management strategies in the study area.

The significant barriers to implementing effective construction waste management strategies in Malaysia metropolis were found to be Lack of attention to waste management in current regulations; Lack of attention to designing buildings according to requirements of waste management; Lack of awareness among contractors about waste management; Stakeholders properly do not have a common understanding among themselves regarding 3R CW management strategies due to the similarity of reducing reuse and recycling strategies.

This paper contributes to the literature to allow academic researchers to replicate similar research using additional variables from different locations and compare the results obtained because the data used in this research may have limited generalizability because it was collected in Malaysia. The results enable project leadership teams to prioritize the workforce, materials, equipment, and time of their construction projects in the planning phase to eliminate the waste generated by the projects, thereby improving efficiency and sustainability. The sustainability approaches proposed in this study can be used as a guideline for any project team to build successful management toolkits for minimizing essential productivity-enhanced SCWmanagement implementation activities. This study has established a basis for improvements in the specifications that could be critical for evaluating and removing waste. Construction waste prevention is significant, leading to avoiding design errors contributing to waste generation. The construction waste is identified chiefly through processes that involve conventional construction.

Author Contributions: For research articles with several authors,

Musa Mohammed: Conceptualization, Investigation, Data curation, Writing -original draft.

Nasir Shafiq: Supervision, Writing- review \& editing.

Ali Elmansoury: Writing- review \& editing

Noor Amila Abdallah Supervision, Writing- review \& editing.

Abubakar Muhammad: Writing- review \& editing.

In the conflict of interest, the authors declare that they have no established conflicting financial interests or personal relationships that may seem to have influenced the research presented in this paper.

Data Availability Statement: Data used and analyzed during this study is available from the corresponding author by request.

Acknowledgments: The authors would like to extend their gratitude to the Universiti Teknologi PETRONAS for the financial and technical support to accomplish this research's objectives. 


\section{References}

[1] S. Singh, P. Rekha, M. J. J. o. M. C. Surya, and W. Management, "Utilization of Linz-Donawitz slag from steel industry for waste minimization," pp. 1-17, 2020.

[2] Z. M. Yaseen, Z. H. Ali, S. Q. Salih, and N. J. S. Al-Ansari, "Prediction of risk delay in construction projects using a hybrid artificial intelligence model," vol. 12, no. 4, p. 1514, 2020.

[3] S. Shahidan, M. A. M. Azmi, K. Kupusamy, S. S. M. Zuki, and N. J. P. e. Ali, "Utilizing construction and demolition (C\&D) waste as recycled aggregates (RA) in concrete," vol. 174, pp. 1028-1035, 2017.

[4] P. Ghisellini, X. Ji, G. Liu, and S. J. J. o. c. p. Ulgiati, "Evaluating the transition towards cleaner production in the construction and demolition sector of China: A review," vol. 195, pp. 418-434, 2018.

[5] A. Maceika, A. Bugajev, and O. R. J. S. Šostak, "The Modelling of Roof Installation Projects Using Decision Trees and the AHP Method," vol. 12, no. 1, p. 59, 2020.

[6] A. Akhtar and A. K. J. J. o. C. P. Sarmah, "Construction and demolition waste generation and properties of recycled aggregate concrete: A global perspective," vol. 186, pp. 262-281, 2018.

[7] Z. Bao, W. Lu, B. Chi, H. Yuan, and J. J. W. M. Hao, "Procurement innovation for a circular economy of construction and demolition waste: Lessons learnt from Suzhou, China," vol. 99, pp. 12-21, 2019.

[8] W. Alattyih, H. Haider, and H. J. S. Boussabaine, "Development of Value Creation Drivers for Sustainable Design of Green Buildings in Saudi Arabia," vol. 11, no. 20, p. 5867, 2019.

[9] K. d. Wong and Q. J. F. Fan, "Building information modelling (BIM) for sustainable building design," 2013.

[10] J. Wang, B. Yu, V. W. Tam, J. Li, and X. J. J. o. C. P. Xu, "Critical factors affecting willingness of design units towards construction waste minimization: An empirical study in Shenzhen, China," vol. 221, pp. 526-535, 2019.

[11] A. Bakchan and K. M. J. W. M. Faust, "Construction waste generation estimates of institutional building projects: Leveraging waste hauling tickets," vol. 87, pp. 301-312, 2019.

[12] J. Won, J. C. Cheng, and G. J. W. M. Lee, "Quantification of construction waste prevented by BIM-based design validation: Case studies in South Korea," vol. 49, pp. 170-180, 2016.

[13] J. Won and J. C. J. A. i. C. Cheng, "Identifying potential opportunities of building information modeling for construction and demolition waste management and minimization," vol. 79, pp. 3-18, 2017.

[14] J. A. J. I. J. o. E. B. M. Hama Kareem, "The impact of intelligent manufacturing elements on product design towards reducing production waste," vol. 11, p. 1847979019863955, 2019.

[15] F. Jalaei, M. Zoghi, and A. J. I. J. o. C. M. Khoshand, "Life cycle environmental impact assessment to manage and optimize construction waste using Building Information Modeling (BIM)," pp. 1-18, 2019.

[16] H. Liu, C. Sydora, M. S. Altaf, S. Han, and M. J. J. o. C. P. Al-Hussein, "Towards sustainable construction: BIMenabled design and planning of roof sheathing installation for prefabricated buildings," vol. 235, pp. 11891201, 2019.

[17] R. Leemans et al., "Developing a common strategy for integrative global environmental change research and outreach: the Earth System Science Partnership (ESSP)," vol. 1, no. 1, pp. 4-13, 2009.

[18] J. J. M. MILLHONE and T. I. i. T. Transfer, "Residential, Commercial, and Institutional Buildings Sector," vol. 3, p. $182,2000$.

[19] N. S. Diffenbaugh et al., "The COVID-19 lockdowns: a window into the Earth System," vol. 1, no. 9, pp. 470481, 2020.

[20] S. Tetali, "Assessment of cool roof technology for its energy performance in buildings," International Institute of Information Technology Hyderabad-500032, India, 2011.

[21] J. J. E. Kneifel and Buildings, "Beyond the code: Energy, carbon, and cost savings using conventional technologies," vol. 43, no. 4, pp. 951-959, 2011.

[22] R. Loonen, M. de Klijn-Chevalerias, and J. J. J. o. B. P. S. Hensen, "Opportunities and pitfalls of using building performance simulation in explorative R\&D contexts," vol. 12, no. 3, pp. 272-288, 2019.

[23] N. Ferronato, V. J. I. j. o. e. r. Torretta, and p. health, "Waste mismanagement in developing countries: A review of global issues," vol. 16, no. 6, p. 1060, 2019.

[24] A. L. Srivastav and A. J. J. o. C. P. Kumar, "An endeavor to achieve sustainable development goals through floral waste management: A short review," p. 124669, 2020. 
[25] N. Ferronato, E. C. Rada, M. A. G. Portillo, L. I. Cioca, M. Ragazzi, and V. J. J. o. e. m. Torretta, "Introduction of the circular economy within developing regions: A comparative analysis of advantages and opportunities for waste valorization," vol. 230, pp. 366-378, 2019.

[26] A. Murgia, M. Ortu, P. Tourani, B. Adams, and S. J. E. S. E. Demeyer, "An exploratory qualitative and quantitative analysis of emotions in issue report comments of open source systems," vol. 23, no. 1, pp. 521$564,2018$.

[27] T. Zuofa and E. J. P. M. J. Ochieng, "Sustainability in construction project delivery: A study of experienced project managers in nigeria," vol. 47, no. 6, pp. 44-55, 2016.

[28] E. Pongrácz, P. S. Phillips, R. L. J. W. T. o. E. Keiski, and t. Environment, "Evolving the Theory of Waste Management: defining key concepts," vol. 78, 2004.

[29] P. N. Cheremisinoff and L. M. Ferrante, Waste reduction for pollution prevention. Butterworth-Heinemann, 2013.

[30] R. A. Begum, C. Siwar, J. J. Pereira, A. H. J. R. Jaafar, conservation, and recycling, "A benefit-cost analysis on the economic feasibility of construction waste minimisation: the case of Malaysia," vol. 48, no. 1, pp. 86-98, 2006.

[31] N. Musee, L. Lorenzen, and C. J. J. o. C. P. Aldrich, "Cellar waste minimization in the wine industry: a systems approach," vol. 15, no. 5, pp. 417-431, 2007.

[32] T. Sabbas et al., "Management of municipal solid waste incineration residues," vol. 23, no. 1, pp. 61-88, 2003.

[33] C.-L. Peng, D. E. Scorpio, C. J. J. C. M. Kibert, and Economics, "Strategies for successful construction and demolition waste recycling operations," vol. 15, no. 1, pp. 49-58, 1997.

[34] M. J. P.-S. Osmani and B. Sciences, "Construction waste minimization in the UK: current pressures for change and approaches," vol. 40, pp. 37-40, 2012.

[35] M. Mohammed, N. Shafiq, N. Abdallah, M. Ayoub, and A. Haruna, "A review on achieving sustainable construction waste management through application of $3 R$ (reduction, reuse, recycling): A lifecycle approach," in IOP Conference Series: Earth and Environmental Science, 2020, vol. 476, no. 1, p. 012010: IOP Publishing.

[36] M. Osmani, J. Glass, and A. D. J. W. m. Price, "Architects' perspectives on construction waste reduction by design," vol. 28, no. 7, pp. 1147-1158, 2008.

[37] K. Ghafourian, S. Ismail, and Z. J. A. S. L. Mohamed, "Construction and Demolition Waste: Its Origins and Causes," vol. 24, no. 6, pp. 4132-4137, 2018.

[38] D. Migilinskas, V. Popov, V. Juocevicius, and L. J. P. E. Ustinovichius, "The benefits, obstacles and problems of practical BIM implementation," vol. 57, pp. 767-774, 2013.

[39] S. Ajayi, "Design, procurement and construction strategies for minimizing waste in construction projects," University of the West of England, 2017.

[40] W. Lu and H. J. W. m. Yuan, "A framework for understanding waste management studies in construction," vol. 31, no. 6, pp. 1252-1260, 2011.

[41] A. A. Najafpoor, A. Zarei, F. Jamali-Behnam, M. Vahedian-Shahroudi, and A. J. I. J. o. H. S. Zarei, "A study identifying causes of construction waste production and applying safety management on construction site," vol. 2, no. 3, pp. 49-54, 2014.

[42] D.-W. O. Imimole, "The identification of non-value adding activities associated with site management in the Nigerian construction industry," Cape Peninsula University of Technology, 2018.

[43] S. O. Ajayi, L. O. Oyedele, M. Bilal, O. O. Akinade, H. A. Alaka, and H. A. J. W. m. Owolabi, "Critical management practices influencing on-site waste minimization in construction projects," vol. 59, pp. 330-339, 2017.

[44] A. Bakshan, I. Srour, G. Chehab, M. J. R. El-Fadel, Conservation, and Recycling, "A field based methodology for estimating waste generation rates at various stages of construction projects," vol. 100, pp. 70-80, 2015.

[45] I. A. Rahman, N. S. M. Akhir, A. H. Memon, and S. Nagapan, "Risk level of factors contributing to waste generation in construction phase," in InCIEC 2014: Springer, 2015, pp. 199-209.

[46] S. Nagapan, I. A. Rahman, and A. J. I. J. o. A. i. A. S. Asmi, "Factors contributing to physical and non-physical waste generation in construction industry," vol. 1, no. 1, pp. 1-10, 2012. 
[47] M. Yeheyis, K. Hewage, M. S. Alam, C. Eskicioglu, R. J. C. t. Sadiq, and e. policy, "An overview of construction and demolition waste management in Canada: a lifecycle analysis approach to sustainability," vol. 15, no. 1, pp. 81-91, 2013.

[48] D. Fatta et al., "Generation and management of construction and demolition waste in Greece-an existing challenge," vol. 40, no. 1, pp. 81-91, 2003.

[49] L. R. Brown, H. Kane, and E. Ayres, "Vital signs 1993: The trends that are shaping our future," WorldWatch Inst., New York, NY (EUA)1993.

[50] N. Lenssen and D. M. Roodman, "Making better buildings," State of the World, pp. 6-6, 1995.

[51] G. Ofori, "The environment: the fourth construction project objective?," Construction Management and Economics, vol. 10, no. 5, pp. 369-395, 1992.

[52] I. R. Panel, U. N. E. P. S. Consumption, and P. Branch, Decoupling natural resource use and environmental impacts from economic growth. UNEP/Earthprint, 2011.

[53] E. Papargyropoulou, C. Preece, R. Padfield, and A. A. Abdullah, "Sustainable construction waste management in Malaysia: A contractor's perspective," in Management and Innovation for a Sustainable Built Environment MISBE 2011, Amsterdam, The Netherlands, June 20-23, 2011, 2011: Citeseer.

[54] A. Al-Hajj, K. J. A. e. Hamani, and d. management, "Material waste in the UAE construction industry: Main causes and minimization practices," vol. 7, no. 4, pp. 221-235, 2011.

[55] M. Osmani, "Construction waste," in Waste, 2011, pp. 207-218: Elsevier.

[56] A. M. Kamar, Z. Abd Hamid, and N. A. J. I. j. o. e. s. Azman, "Industrialized building system (IBS): Revisiting issues of definition and classification," vol. 1, no. 2, p. 120, 2011.

[57] N. J. E. Umeokafor, Construction and A. Management, "An investigation into public and private clients' attitudes, commitment and impact on construction health and safety in Nigeria," 2018.

[58] A. Opoku, V. Ahmed, H. Cruickshank, S. Senaratne, P. R. J. B. E. P. Hewamanage, and A. Management, "The role of team leadership in achieving LEED certification in a green building project," 2015.

[59] I. J. J. o. P. A. Bostan, Finance and Law, "Considerations on insufficient legal regulation of special allocations made by the central executive authority," no. 09, pp. 119-124, 2016.

[60] A. Saleem et al., "Knowledge and awareness of cervical cancer in Southwestern Ethiopia is lacking: A descriptive analysis," vol. 14, no. 11, p. e0215117, 2019.

[61] B. R. Johnson, E. Connolly, T. S. J. C. S. R. Carter, and E. Management, "Corporate social responsibility: The role of Fortune 100 companies in domestic and international natural disasters," vol. 18, no. 6, pp. 352-369, 2011.

[62] Y. Chen, G. E. Okudan, and D. R. J. A. i. c. Riley, "Sustainable performance criteria for construction method selection in concrete buildings," vol. 19, no. 2, pp. 235-244, 2010.

[63] U. A. Umar, N. Shafiq, A. Malakahmad, M. F. Nuruddin, M. F. J. J. o. M. C. Khamidi, and W. Management, "A review on adoption of novel techniques in construction waste management and policy," vol. 19, no. 4, pp. 1361-1373, 2017.

[64] N. Duić, K. Urbaniec, and D. J. J. o. C. P. Huisingh, "Components and structures of the pillars of sustainability," vol. 88, pp. 1-12, 2015.

[65] A. Ali, "Development of a framework for sustainable construction waste management. A case study of three major Libyan cities," 2018.

[66] M. Grosz, "Chapter III. Addressing The Waste Trade In The Context Of Sustainability," in Sustainable Waste Trade under WTO Law: Brill Nijhoff, 2011, pp. 277-327.

[67] H. M. Gregersen, P. F. Ffolliott, and K. N. Brooks, Integrated watershed management: Connecting people to their land and water. CABI, 2007.

[68] I. J. C. FREDA, Environment and Ecopolitics, "CHAPTER TEN ECOPOLITICAL ACTION ON THE DESERT OF THE REAL," p. 255, 2020.

[69] H. G. He et al., "Nurses' use of non-pharmacological methods in children's postoperative pain management: educational intervention study," vol. 66, no. 11, pp. 2398-2409, 2010.

[70] M. I. Aziz, A. Afthanorhan, Z. J. C. B. Awang, and Management, "Talent development model for a career in Islamic banking institutions: A SEM approach," vol. 3, no. 1, p. 1186259, 2016. 
[71] B. Ishiyaku, R. Kasim, and A. J. J. o. B. P. Harir, "Confirmatory factoral validity of public housing performance evaluation constructs," vol. 7, no. 1, 2016.

[72] T. W. Hall, T. L. Herron, B. J. Pierce, T. J. J. A. A. J. o. P. Witt, and Theory, "The effectiveness of increasing sample size to mitigate the influence of population characteristics in haphazard sampling," vol. 20, no. 1, pp. 169-185, 2001.

[73] C. L. Parr, M. B. Veierød, P. Laake, E. Lund, and A. J. N. j. Hjartåker, "Test-retest reproducibility of a food frequency questionnaire (FFQ) and estimated effects on disease risk in the Norwegian Women and Cancer Study (NOWAC)," vol. 5, no. 1, p. 4, 2006.

[74] T. A. Heberlein and R. J. A. s. r. Baumgartner, "Factors affecting response rates to mailed questionnaires: A quantitative analysis of the published literature," pp. 447-462, 1978.

[75] K. S. J. R. i. S. E. Taber, "The use of Cronbach's alpha when developing and reporting research instruments in science education," vol. 48, no. 6, pp. 1273-1296, 2018.

[76] K. K.-K. J. M. B. Wong, "Mediation analysis, categorical moderation analysis, and higher-order constructs modeling in Partial Least Squares Structural Equation Modeling (PLS-SEM): A B2B Example using SmartPLS," vol. 26, 2016.

[77] R. Eisinga, M. Te Grotenhuis, and B. J. I. j. o. p. h. Pelzer, "The reliability of a two-item scale: Pearson, Cronbach, or Spearman-Brown?," vol. 58, no. 4, pp. 637-642, 2013.

[78] A. Gouldson, A. Sudmant, H. Khreis, and E. J. C. f. U. T. W. Papargyropoulou, DC, USA, "The economic and social benefits of low-carbon cities: a systematic review of the evidence," 2018.

[79] S. K. Sharma, M. Sarrab, and H. J. I. L. E. Al-Shihi, "Development and validation of mobile learning acceptance measure," vol. 25, no. 7, pp. 847-858, 2017.

[80] M. I. Aguirre-Urreta and M. J. M. q. Rönkkö, "Statistical inference with PLSc using bootstrap confidence intervals," vol. 42, no. 3, pp. 1001-1020, 2018.

[81] I. A. Rahman, A. H. Memon, A. A. A. Aziz, N. H. J. R. J. o. A. S. Abdullah, Engineering, and Technology, "Modeling causes of cost overrun in large construction projects with partial least square-SEM approach: contractor's perspective," vol. 5, no. 06, pp. 1963-1972, 2013.

[82] M. Sarstedt, J. F. Hair Jr, J.-H. Cheah, J.-M. Becker, and C. M. J. A. M. J. Ringle, "How to specify, estimate, and validate higher-order constructs in PLS-SEM," vol. 27, no. 3, pp. 197-211, 2019.

[83] J. F. Hair Jr, M. C. Howard, and C. J. J. o. B. R. Nitzl, "Assessing measurement model quality in PLS-SEM using confirmatory composite analysis," vol. 109, pp. 101-110, 2020.

[84] J. F. Hair Jr, M. Sarstedt, L. Hopkins, and V. G. J. E. b. r. Kuppelwieser, "Partial least squares structural equation modeling (PLS-SEM): An emerging tool in business research," 2014.

[85] J. F. Hair Jr, L. M. Matthews, R. L. Matthews, and M. J. I. J. o. M. D. A. Sarstedt, "PLS-SEM or CB-SEM: updated guidelines on which method to use," vol. 1, no. 2, pp. 107-123, 2017.

[86] J. Henseler, G. Hubona, P. A. J. I. m. Ray, and d. systems, "Using PLS path modeling in new technology research: updated guidelines," 2016.

[87] M. Janadari, S. Sri Ramalu, and C. Wei, "Evaluation of measurment and structural model of the reflective model constructs in PLS-SEM," 2016.

[88] J. Henseler and M. J. C. s. Sarstedt, "Goodness-of-fit indices for partial least squares path modeling," vol. 28, no. 2, pp. 565-580, 2013.

[89] F. T. Al Mansoori, I. A. Rahman, R. J. I. J. o. S. C. E. Kasim, and Technology, "Structural Relationship of Factors Affecting the Performance of Oil \& Gas Company: Case Study of Adnoc," vol. 11, no. 2, pp. 140-149, 2020.

[90] M. A. Adabre, A. P. J. J. o. U. P. Chan, and Development, "Modeling the impact of barriers on sustainable housing in developing countries," vol. 147, no. 1, p. 05020032, 2021.

[91] J. Liu, Y. Yi, and X. J. J. o. C. P. Wang, "Exploring factors influencing construction waste reduction: A structural equation modeling approach," vol. 276, p. 123185, 2020.

[92] A. A. M. Bohari, M. Skitmore, B. Xia, and M. J. J. o. c. P. Teo, "Green oriented procurement for building projects: Preliminary findings from Malaysia," vol. 148, pp. 690-700, 2017.

[93] K. Kabirifar, M. Mojtahedi, C. Wang, and V. W. J. J. o. C. P. Tam, "Construction and demolition waste management contributing factors coupled with reduce, reuse, and recycle strategies for effective waste management: A review," p. 121265, 2020. 
[94] S. O. Ajayi et al., "Waste effectiveness of the construction industry: Understanding the impediments and requisites for improvements," vol. 102, pp. 101-112, 2015.

[95] B. Nikmehr et al., "An integrated model for factors affecting construction and demolition waste management in Iran," 2017.

[96] S. Lockrey, K. Verghese, E. Crossin, and H. J. J. o. c. p. Nguyen, "Concrete recycling life cycle flows and performance from construction and demolition waste in Hanoi," vol. 179, pp. 593-604, 2018.

[97] Z. Liu, M. Osmani, P. Demian, and A. J. A. i. c. Baldwin, "A BIM-aided construction waste minimisation framework," vol. 59, pp. 1-23, 2015.

[98] J. A. Bamgbade, A. M. Kamaruddeen, and M. J. R. T. D. L. F. D. I. U. D. Z. Nawi, "Factors influencing sustainable construction among construction firms in Malaysia: A preliminary study using PLS-SEM," vol. 38, no. 3, pp. 132-142, 2015.

[99] S. Nagapan, I. A. Rahman, A. Asmi, A. H. Memon, and I. Latif, "Issues on construction waste: The need for sustainable waste management," in 2012 IEEE Colloquium on Humanities, Science and Engineering (CHUSER), 2012, pp. 325-330: IEEE.

[100] L. Jingkuang and W. J. S. E. P. Yousong, "Establishment and application of performance assessment model of waste management in architectural engineering projects in China," vol. 1, pp. 147-155, 2011.

[101] E. J. W. M. Manowong and Research, "Investigating factors influencing construction waste management efforts in developing countries: an experience from Thailand," vol. 30, no. 1, pp. 56-71, 2012.

[102] P. O. Akadiri and O. O. J. C. I. Fadiya, "Empirical analysis of the determinants of environmentally sustainable practices in the UK construction industry," 2013. 